\title{
FÜGGESZTETT GERENDACSALÁD SZABADREZGÉSE I.
}

\author{
SAJÁTFREKVENCIÁK ÉS REZGÉSALAKOK SZÁMÍTÁSA
}

\author{
GELEJI BORBÁLA* - NÉMETH RÓBERT KÁROLY** \\ *PhD hallgató. BME Tartószerkezetek Mechanikája Tanszék, 1111 Budapest, Műegyetem rkp. 3. \\ E-mail: geleji.borbala@epito.bme.hu \\ **PhD, egyetemi docens. BME Tartószerkezetek Mechanikája Tanszék, 1111 Budapest, Müegyetem rkp. 3. \\ Fax: +36-1-463-1099. E-mail: nemeth.robert@epito.bme.hu
}

\begin{abstract}
Cikkünkben egy újfajta szerkezeti megoldás, a kötéllel történő csigasoros felfüggesztés szabadrezgésre gyakorolt hatását vizsgáljuk meg egy hajlított gerendacsalád esetén. A gerendacsalád minden tagja szimmetrikus kéttámaszú tartó, amit egy csigasoron átvezetett, végtelen merevnek és elhanyagolható tömegünek tekintett kötél is megtámaszt a szimmetrikusan elhelyezkedö felfüggesztési pontokban. A felfüggesztés csigáinak tehetetlenségi nyomatékát és a súrlódást elhanyagoljuk. A függesztőkötél kétféle állapota a szerkezet viselkedését általános esetben nemlineárissá teszi, de még ilyenkor is vizsgálható szakaszonként lineáris szerkezetként. A függesztőkötél megfeszített állapotához tartozó sajátkörfrekvenciák és rezgésalakok ismerete lehetővé teszi a modálanalízis alkalmazását a szerkezet rezgésének számítása során. A rezgésalakokat és a sajátfrekvenciákat a frekvenciaparaméter és egy, a felfüggesztési pontok helyzetét meghatározó paraméter függvényében állítjuk elö. Ehhez a paraméterek segítségével írjuk fel a folytonossági és peremfeltételeket kifejező frekvenciamátrixot. A frekvenciamátrix determinánsának zérushelyeit keresve bemutatjuk, hogyan vezethető vissza a determináns számítása egy kisebb méretủ mátrix determinánsának számítására. E kisebb méretủ mátrix determinánsa ugyanazokra a frekvenciaparaméterekre ad zérust, mint a frekvenciamátrix determinánsa.
\end{abstract}

Kulcsszavak: csigasoros függesztés, többszabadságfokú kényszer, szabadrezgés

\section{BEVEZETÉS}

A több elmozdulás lineáris kombinációjára valamilyen feltételt megfogalmazó kényszerek egyik hatása, hogy a statikai határozatlanság fokát és ezzel a szerkezet merevségét csak kisebb mértékben növelik meg, mintha az egyes elmozdulások mindegyikére külön-külön írnánk elő valamilyen kényszert. Ilyen szerkezeti megoldást eredményez például a csigasorral történő felfüggesztés (Kolozsváry-Kiss 2006, Hincz 2007, Hincz 2009). E szerkezeti megoldással egyenletes erőbevezetés érhető el, ami ráadásul szükség esetén egyetlen paraméterrel könnyen szabályozható. Az így kialakított szerkezet könnyü, ezért érzékeny a dinamikus hatásokra. A rezgések során azonban nagy amplitúdó mellett a kötélben a húzóerő eltünhet, ezzel a felfüggesztés passzívvá válhat. Ez az állapotváltozás a rezgést nemlineárissá teszi, bár szakaszonként továbbra is lineáris marad a szerkezet viselkedése. Korábban kimutattuk, hogy a rezgés vizsgálatának még a nemlineáris esetben is hatékony eszköze lehet a szakaszonként lineáris állapotok modálanalízise (Kocsis 2015, Németh 2015). Megfelelö mértékü statikus elöterhelés esetén az is biztosítható, hogy a kötél nem 
lazul meg, így a felfüggesztés nem válik passzívvá. Ilyenkor továbbra is elegendő a lineáris állapot vizsgálata.

Fentiek miatt célunk, hogy egy korábban vizsgált szerkezetet általánosítsunk a felfüggesztések száma és helye tekintetében. Ezen paraméterek függvényében határozzuk meg a szerkezet sajátfrekvenciáit és rezgésalakjait.

Cikkünk további fejezeteiben bemutatjuk a vizsgálni kívánt szerkezetek családját és a vizsgálat módját, és példát mutatunk annak alkalmazására.

\section{VIZSGÁLATUNK TÁRGYA}

Egy kéttámaszú gerenda hajlítórezgéseit fogjuk vizsgálni abban az esetben, ha egy szimmetrikusan elhelyezett csigasoron átvezetett kötéllel függesztjük fel. A gerenda prizmatikus, keresztmetszete a vizsgálat síkjára szimmetrikus, hajlítómerevsége állandó, tömegeloszlása egyenletes. A kötél nyújthatatlan, tömege elhanyagolható. A csigákat súrlódásmentesnek tételezzük fel, a méretüket pedig kellően kicsinynek tekintjük ahhoz, hogy a tömegüket és tehetetlenségi nyomatékukat elhanyagoljuk és az átvezetett kötélszakasz hosszának az egyenes szakaszhoz viszonyított aránya csak elhanyagolható mértékben változzon a mozgás során. A tömeg elhanyagolása miatt a kötél minden ágában ugyanakkora kötélerő lép fel. Az elmozdulások nagyságrendjéről feltételezzük, hogy érvényes marad a kis elmozdulások elve.

Két szerkezettípust fogunk vizsgálni, melyekre egy-egy példát mutat az 1. ábra. Az első típusban a gerendát $2 c$ pontban függesztjük fel szimmetrikusan egy csigákon átvezetett kötéllel (lásd az 1.a) ábrát $c=3$ esetén). A második típusban $2 c+1$ felfüggesztési pont kapcsolódik a gerendához szimmetrikus elrendezésben (lásd az 1.b) ábrát $c=2$ esetén).

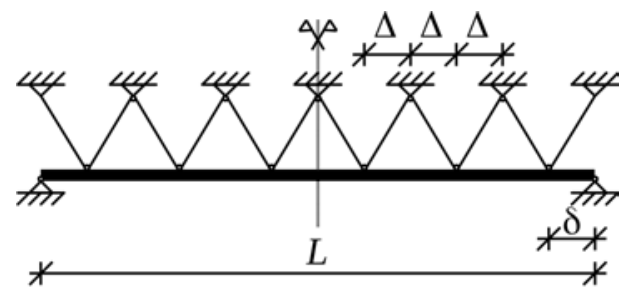

a)

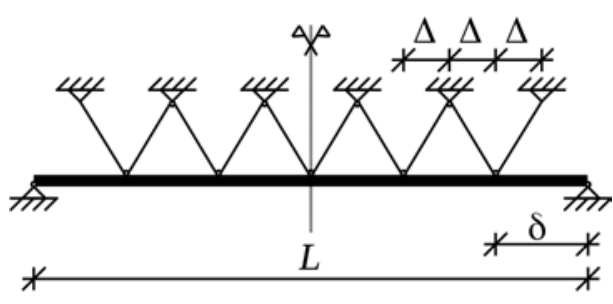

b)

1. ábra. Páros $a$ ) és páratlan b) csigával szimmetrikusan felfüggesztett gerenda

Mindkét típus esetén két paraméterrel jellemezzük a család tagját: egy egyenes kötélszakasz vízszintes vetületének hosszával $(\Delta)$ és a felfüggesztési pontok számát $(2 c$, illetve $2 c+1)$ meghatározó $c$-vel. Mivel felfüggesztési pont csak a gerendán 
képzelhetö el, ezért a $(2 c-1) \Delta \leq L / 2$, illetve a $2 c \Delta \leq L / 2$, feltételnek teljesülni kell, de nem követeljük meg, hogy annyi felfüggesztési pont legyen, amennyi elfér.

Mindkét esetben szimmetrikus szerkezetről beszélhetünk, ezért a sajátrezgésalakok is szimmetrikus vagy ferdén szimmetrikus alakok lesznek (Ludvig 1983). (Ez alól akkor lehet kivétel, ha egy egyszerre szimmetrikus és ferdén szimmetrikus alakhoz tartozó frekvenciaparaméter többszörös gyök, de az ilyen esetben is választható egy szimmetrikus és egy ferdén szimmetrikus rezgésalak bázisnak.) A ferdén szimmetrikus alakoknál a felfüggesztési pontok elmozdulásai páronként egymás ellentettjei lesznek, így ezekben a rezgésalakokban a kötél hossza anélkül marad változatlan, hogy benne erő ébredne. Emiatt a kötél nélküli kéttámaszú tartó ferdén szimmetrikus rezgésalakjaival megegyező alakokat kapunk (kettő, négy, hat stb. szinusz-félhullámot) a nekik megfelelő sajátfrekvenciákkal és frekvenciaparaméterekkel. A szimmetrikus rezgésalakok esetén lehetséges eltérés a kötél nélküli esethez képest, ezért vizsgálatunkat ezen alakok meghatározására szükítjük. A rezgés során feltételezzük, hogy a kötél nem válik passzívvá: ez elérhető például úgy, hogy az önsúly hatására kialakuló statikus elmozduláshoz képest a rezgés amplitúdója csak akkora lehet, hogy a kötél még húzott maradjon. Ennek megfelelően csak az aktív kötéllel, de több ponton felfüggesztett rúd rezgésalakjait és sajátfrekvenciáit keressük.

A két szerkezettípusban közös, hogy a szabadrezgés differenciálegyenlete (Timoshenko 1974):

$$
\mu \ddot{u}(x, t)+\operatorname{EIu}^{\prime \prime \prime \prime}(x, t)=0,
$$

ahol $\mu$ a gerenda fajlagos tömege, $E I$ a gerenda hajlítómerevsége, $u(x, t)$ a gerenda lehajlása a statikus teher hatására kialakult egyensúlyi helyzethez képest, a (') szimbólum az $x$ hely, a $(\cdot)$ szimbólum a $t$ idő szerinti deriválást jelenti. A mértékegységeket úgy választjuk meg, hogy a rúd hossza egységnyi legyen. A szimmetria kihasználása érdekében a koordináta-rendszer kezdőpontját a gerenda középpontjába helyezzük. A szabadrezgés-feladat megoldását a változók szétválasztásával keressük $u(x, t)=u(x) \cos \left(\omega_{0} t-\varphi_{0}\right)$ alakban, amit a differenciálegyenletbe behelyettesítve az $u(x)$ alakfüggvényre a

$$
-\omega_{0}^{2} \mu u(x)+\operatorname{EIu}^{\prime \prime \prime \prime}(x)=0
$$

közönséges differenciálegyenletet kapjuk. A felfüggesztési pontokban az ottani csigán átvezetett kötél két ágában ébredő erő eredője hat a gerendára. Mivel mindkét kapcsolódó kötélágban azonos a kötélerő vízszintessel bezárt szöge, és a kötélerő is mindkét ágban azonos, ezért a gerendára ható eredő egy függőleges erő lesz. A felfüggesztésről átadódó erő ugrást okoz a nyíróerő függvényében, ami az elmozdulásfüggvény harmadik deriváltjával arányos. Emiatt a felfüggesztési pontok szakaszokra osztják az elmozdulásfüggvényt. Az egyes szakaszokon a megoldás általános alakja 


$$
u(x)=A_{r} \cos (\lambda x)+B_{r} \sin (\lambda x)+C_{r} \cosh (\lambda x)+D_{r} \sinh (\lambda x)
$$

lesz, ahol $\lambda$ a frekvenciaparaméter. A differenciálegyenletbe való visszahelyettesítés alapján a sajátkörfrekvencia és a frekvenciaparaméter közötti kapcsolat az $L=1$ feltétel mellett $\omega_{0}=\lambda^{2} \sqrt{E I / \mu}$. Általános (azaz nem egységnyi) $L$ gerendahossz esetén a továbbiakban bemutatott összefüggésekben $\lambda$ értékét az $L$ hosszúsággal osztani kell, így a sajátkörfrekvenciát az

$$
\omega_{0}=\frac{\lambda^{2}}{L^{2}} \sqrt{\frac{E I}{\mu}}
$$

képlettel számíthatjuk.

\section{A FREKVENCIAMÁTRIX ÉS DETERMINÁNSÁNAK ELÖÁLLÍTÁSA}

A diszkrét pontokban felfüggesztett gerendák esetén a frekvenciaparamétert a frekvenciamátrix determinánsának zérushelyeinek meghatározásával találhatjuk meg. Az alábbiakban bemutatjuk, hogy a frekvenciamátrixot milyen szisztematikus algoritmus szerint lehet előállítani az általunk vizsgált két szerkezettípus esetén, és a determináns számításához hogyan lehet egyszerüsíteni a feladatot egy kisebb méretü mátrix létrehozásával.

A rezgésalakot az (1) rezgésegyenlet általános megoldása alapján határozzuk meg. Eszerint két felfüggesztési pont közötti $r$-edik szakaszon az alakot az

$$
A_{r} \cos (\lambda \xi)+B_{r} \sin (\lambda \xi)+C_{r} \cosh (\lambda \xi)+D_{r} \sinh (\lambda \xi)
$$

függvény adja meg, ahol a $\xi$ változót az $x$ eltolásával minden szakasz elején 0 -tól indítjuk. Az $A_{r}, B_{r}, C_{r}, D_{r}$ paramétereket perem- és csatlakozási feltételek alapján számíthatjuk.

Számításaink során kihasználjuk a szerkezet szimmetriáját, így szétválaszthatjuk a ferdén szimmetrikus és a szimmetrikus rezgésalakokat. Ennek következtében a frekvenciamátrix mérete felére csökkenthető. A ferdén szimmetrikus rezgésalakok esetén a kötélben nem ébred húzóerő, így nem történik a megoldásfüggvényben a nyíróerő ugrása miatti változás: a ferdén szimmetrikus alakok a páros szinusz-félhullámok lesznek. A $k$-adik ferdén szimmetrikus alak esetén a frekvenciaparaméter értéke $\lambda_{f, k}=2 k \pi$ lesz, a hozzá tartozó rezgésalak pedig:

$$
u_{f, k}(x)=\sqrt{2} \sin (2 k \pi x) \text {. }
$$

Az $f$ index a ferdén szimmetrikus alakra utal. Emlékeztetünk, hogy $x$ értéke $-0,5$ és 0,5 között értelmezett, a $\sqrt{2}$ szorzó a normálás miatt jelenik meg. 
A továbbiakban a frekvenciamátrix előállítását mutatjuk be a szimmetrikus rezgésalakokra páros és páratlan felfüggesztési pont esetén. A követhetőség érdekében a szimmetrikus alakra való utalást nem jelenítjük meg a paraméterek, változók jelölésében.

\subsection{PÁROS FELFÜGGESZTÉSI PONT, KÖZÉPPONTBAN NEM FELFÜGGESZTETT GERENDA}

Mivel csak a szimmetrikus rezgésalakokat kell keresnünk, ezért elegendő a fél gerenda vizsgálata a tartó közepétől a végéig. Az egyes szakaszokon a $\xi$ paramétert mindig 0 -tól indítjuk, ami az $x$-koordináta eltolásának feleltethető meg. Így az egyes szakaszok végén a $\xi$ értéke $2 \Delta$ lesz. Ez alól két kivétel lesz: az első szakaszon már $\Delta$ pontban van a felfüggesztés, az utolsó szakasz hossza pedig $\delta=0,5-(2 c-1) \Delta$ lesz. A szimmetriafeltételből adódik, hogy a gerenda közepén az elfordulás és a nyíróerö, azaz az első és a harmadik derivált értéke nulla lesz. E két feltételből $B_{1}=D_{1}=0$ lesz. A fennmaradó ismeretlen paraméterekkel az alakfüggvényt az alábbiak szerint adjuk meg:

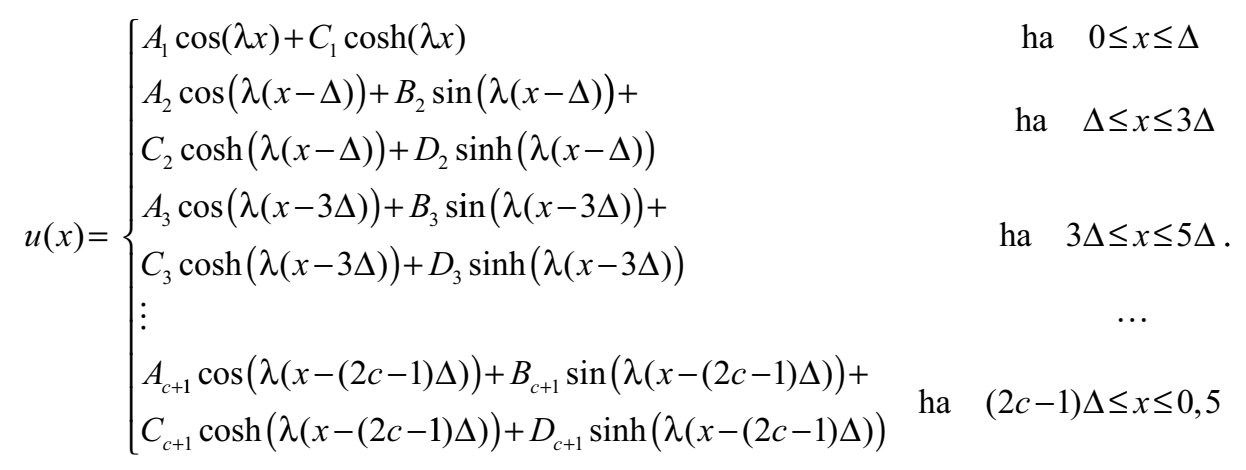

A perem- és csatlakozási feltételek a következők:

Az első két feltétel a tartó végén levő csuklós megtámasztás. Itt az eltolódás és a hajlítónyomaték zérus. Mivel utóbbi a görbülettel, és így az eltolódás második deriváltjával arányos, ezért a feltételek:

$$
\begin{gathered}
u_{c+1}(\delta)=A_{c+1} \cos (\lambda \delta)+B_{c+1} \sin (\lambda \delta)+C_{c+1} \cosh (\lambda \delta)+D_{c+1} \sinh (\lambda \delta)=0 \\
u_{c+1}^{\prime \prime}(\delta)=\lambda^{2}\left(-A_{c+1} \cos (\lambda \delta)-B_{c+1} \sin (\lambda \delta)+C_{c+1} \cosh (\lambda \delta)+D_{c+1} \sinh (\lambda \delta)\right)=0 .
\end{gathered}
$$

A harmadik feltétel a kötél megnyúlására vonatkozik, eszerint a felfüggesztési pontok eltolódásainak összege zérus. A szimmetrikus alakok miatt elegendő a vizsgált félen levő felfüggesztési pontok eltolódásainak összegét elöírni. Célszerüen minden felfüggesztési pont eltolódását a felfüggesztést követő szakasz elmozdulás- 
függvényével írhatjuk fel, így (a $\sin 0=\sinh 0=0$ és $\cos 0=\cosh 0=1$ következtében):

$$
\sum_{r=1}^{c} u_{r+1}(0)=\sum_{r=1}^{c}\left(A_{r+1}+C_{r+1}\right)=0 .
$$

A következő csoport a folytonossági feltételeket fejezi ki a felfüggesztési pontokban. Az első felfüggesztési pontban azt kell biztosítanunk, hogy a balról, illetve jobbról számított eltolódások, elfordulások és hajlítónyomatékok azonosak legyenek. Ez a jobbról és balról számított függvényértékek, első deriváltak és második deriváltak egyenlőségeként írható le:

$$
\begin{gathered}
u_{1}(\lambda \Delta)-u_{2}(0)=A_{1} \cos (\lambda \Delta)+C_{1} \cosh (\lambda \Delta)-A_{2}-C_{2}=0 \\
u_{1}^{\prime}(\lambda \Delta)-u_{2}^{\prime}(0)=\lambda\left\{-A_{1} \sin (\lambda \Delta)+C_{1} \sinh (\lambda \Delta)-B_{2}-D_{2}\right\}=0 \\
u_{2}^{\prime \prime}(\lambda \Delta)-u_{2}^{\prime \prime}(0)=\lambda^{2}\left\{-A_{1} \cos (\lambda \Delta)+C_{1} \cosh (\lambda \Delta)+A_{2}-C_{2}\right\}=0 .
\end{gathered}
$$

A többi felfüggesztési pontban (minden $r>1$-re) ugyanezt a folytonosságot kell biztosítani:

$$
\begin{aligned}
& u_{r}(2 \lambda \Delta)-u_{r+1}(0)= \\
& A_{r} \cos (2 \lambda \Delta)+B_{r} \sin (2 \lambda \Delta)+C_{r} \cosh (2 \lambda \Delta)+D_{r} \sinh (2 \lambda \Delta)-A_{r+1}-C_{r+1}=0 \\
& u_{r}^{\prime}(2 \lambda \Delta)-u_{r+1}^{\prime}(0)= \\
& \lambda\left\{-A_{r} \sin (2 \lambda \Delta)+B_{r} \cos (2 \lambda \Delta)+C_{r} \sinh (2 \lambda \Delta)+D_{r} \cosh (2 \lambda \Delta)-B_{r+1}-D_{r+1}\right\}=0 \\
& u_{r}^{\prime \prime}(2 \lambda \Delta)-u_{r+1}^{\prime \prime}(0)= \\
& \lambda^{2}\left\{-A_{r} \cos (2 \lambda \Delta)-B_{r} \sin (2 \lambda \Delta)+C_{r} \cosh (2 \lambda \Delta)+D_{r} \sinh (2 \lambda \Delta)+A_{r+1}-C_{r+1}\right\}=0 .
\end{aligned}
$$

továbbá azt, hogy a nyíróerő kötélerő miatti ugrása ugyanakkora legyen, mint az első felfüggesztési pontban, hiszen a gerendára átadódó kötélerők eredője mindegyik felfüggesztési pontban ugyanakkora. Ez a feltétel a harmadik derivált ugrásaként adható meg:

$$
\begin{aligned}
& \left(u_{1}^{\prime \prime \prime}(\lambda \Delta)-u_{2}^{\prime \prime \prime}(0)\right)-\left(u_{r}^{\prime \prime \prime}(2 \lambda \Delta)-u_{r+1}^{\prime \prime \prime}(0)\right)= \\
& \lambda^{3}\left\{\begin{array}{l}
\left(A_{1} \sin (\lambda \Delta)+C_{1} \sinh (\lambda \Delta)+B_{2}-D_{2}\right)- \\
\left(A_{r} \sin (2 \lambda \Delta)-B_{r} \cos (2 \lambda \Delta)+C_{r} \sinh (2 \lambda \Delta)+D_{r} \cosh (2 \lambda \Delta)+B_{r+1}-D_{r+1}\right)
\end{array}\right\}=0 .
\end{aligned}
$$


Az ismeretleneket a $\boldsymbol{c}=\left[A_{1}, C_{1}, A_{2}, B_{2}, C_{2}, D_{2}, \ldots D_{c+1}\right]^{T}$ vektorba gyüjtve a fenti feltételeket röviden $\boldsymbol{F} \boldsymbol{c}=\mathbf{0}$ alakban is írhatjuk, ahol $\boldsymbol{F}$ a frekvenciamátrix. A frekvenciamátrix egy-egy sora az elöbb ismertetett feltételek egyikét tartalmazza. Írjuk a feltételi egyenleteket az ismertetés sorrendjében, az egyes felfüggesztési pontokhoz tartozó (6) és (7) egyenleteket összevonva, és ahol lehetséges, a $\lambda$ hatványával leosztva egyszerüsítsük azokat. Így az egyenletrendszer mátrixos alakja $c=4$ esetben az alábbi lesz:

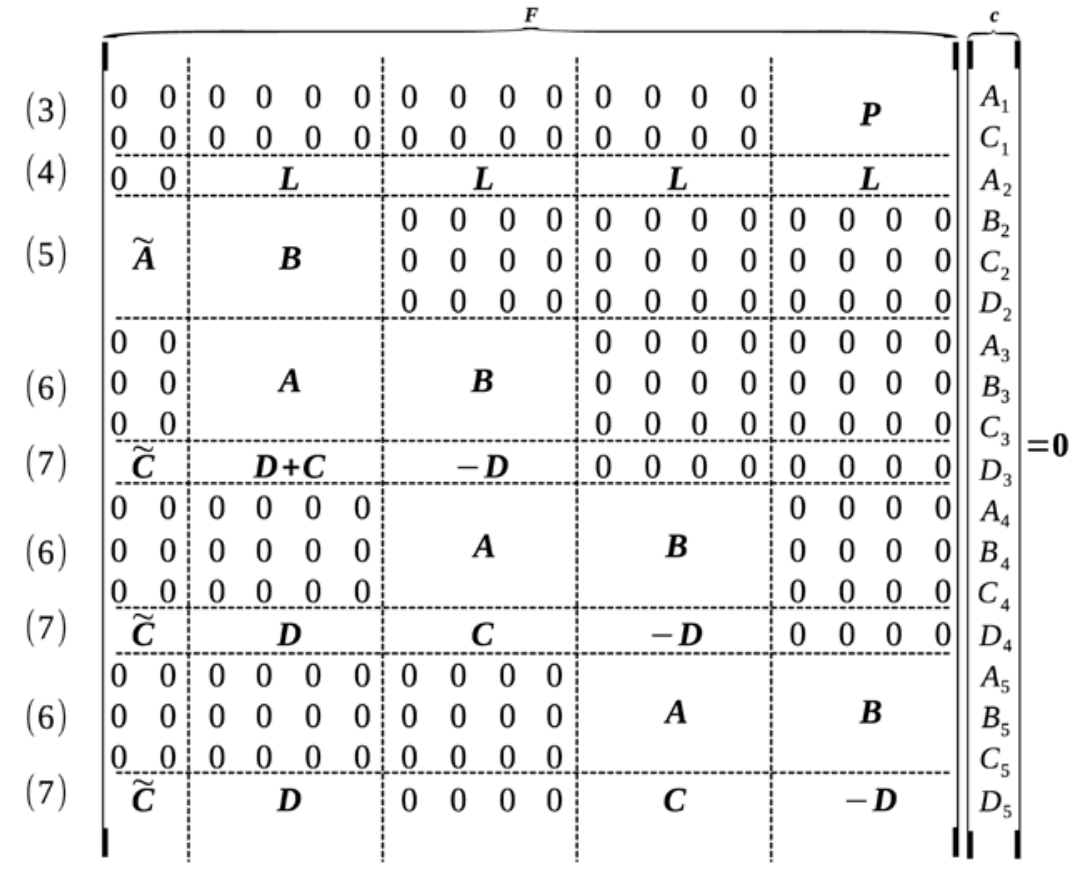

A mátrixot vízszintesen a (3-7) feltételi egyenletek szerint osztottuk fel szaggatott vonalakkal, függőlegesen pedig az egyes gerendaszakaszokhoz tartozó paraméterek együtthatóinak megfelelően rajzoltunk be szaggatott vonalakat. Az egyes mátrixsorok csoportjai előtt jeleztük az adott sorokat meghatározó egyenleteket. A mátrix nemzérus elemeit az alábbi segédmátrixok segítségével adtuk meg a (8) egyenletben: 


$$
\begin{aligned}
& \boldsymbol{P}=\left[\begin{array}{cccc}
\cos (\lambda \delta) & \sin (\lambda \delta) & \cosh (\lambda \delta) & \sinh (\lambda \delta) \\
-\cos (\lambda \delta) & -\sin (\lambda \delta) & \cosh (\lambda \delta) & \sinh (\lambda \delta)
\end{array}\right], \\
& \boldsymbol{L}=\left[\begin{array}{llll}
1 & 0 & 1 & 0
\end{array}\right] \text {, } \\
& \tilde{\boldsymbol{A}}=\left[\begin{array}{ll}
\cos (\lambda \Delta) & \cosh (\lambda \Delta) \\
-\sin (\lambda \Delta) & \sinh (\lambda \Delta) \\
-\cos (\lambda \Delta) & \cosh (\lambda \Delta)
\end{array}\right], \quad \boldsymbol{B}=\left[\begin{array}{cccc}
-1 & 0 & -1 & 0 \\
0 & -1 & 0 & -1 \\
1 & 0 & -1 & 0
\end{array}\right], \\
& \boldsymbol{A}=\left[\begin{array}{llll}
\cos (2 \lambda \Delta) & \sin (2 \lambda \Delta) & \cosh (2 \lambda \Delta) & \sinh (2 \lambda \Delta) \\
-\sin (2 \lambda \Delta) & \cos (2 \lambda \Delta) & \sinh (2 \lambda \Delta) & \cosh (2 \lambda \Delta) \\
-\cos (2 \lambda \Delta) & -\sin (2 \lambda \Delta) & \cosh (2 \lambda \Delta) & \sinh (2 \lambda \Delta)
\end{array}\right], \\
& \tilde{\boldsymbol{C}}=\left[\begin{array}{ll}
\sin (\lambda \Delta) & \sinh (\lambda \Delta)
\end{array}\right], \quad \boldsymbol{D}=\left[\begin{array}{llll}
0 & 1 & 0 & -1
\end{array}\right], \\
& \boldsymbol{C}=\left[\begin{array}{llll}
-\sin (2 \lambda \Delta) & \cos (2 \lambda \Delta) & -\sinh (2 \lambda \Delta) & -\cosh (2 \lambda \Delta)
\end{array}\right] .
\end{aligned}
$$

A mátrix struktúrája ebből a felírásból már jól kiolvasható. Újabb felfüggesztési pont esetén a sorok és oszlopok száma is néggyel növekszik, a $\boldsymbol{P}$ blokk jobbra tolódik négy hellyel, helyére egy $2 \times 4$-méretű zérusmátrix kerül. A harmadik sorban a $\boldsymbol{P}$ mátrix alatt egy $\boldsymbol{L}$ blokk jelenik meg. A mátrix utolsó sorának elejére egy $[\tilde{\boldsymbol{C}} \boldsymbol{D}]$ blokk kerül, míg a jobb alsó sarokban levő $4 \times 8$-as blokkhoz az

$$
\left[\begin{array}{cc}
A & B \\
C & -D
\end{array}\right]
$$

blokkot kell hozzáadni. Ezzel a recepttel a mátrix tetszőleges számú felfüggesztési pontra felírható.

Visszafelé haladva a felfüggesztési pontok számának csökkentésével a $c=1$ esethez, vagyis az oldalankénti egyetlen felfüggesztési ponthoz már csak a 6×6-os méretü

$$
\left[\begin{array}{cc}
\mathbf{0} & P \\
\mathbf{0} & L \\
\tilde{A} & B
\end{array}\right]
$$

mátrix tartozik.

A $\lambda$ frekvenciaparaméterek azok az értékek, ahol a (8) egyenlet alakjában megadott homogén egyenletnek nemtriviális megoldása van, azaz az $\boldsymbol{F}$ determinánsa 0 . A felfüggesztési pontok számának növekedésével azonban növekszik a mátrix mérete, és így a determináns számításához elvégzendő műveletek száma is. Ez a számítási igény jelentősen csökkenthető a mátrix speciális szerkezetének kihasználásával.

Particionáljuk a frekvenciamátrixot

$$
F=\left[\begin{array}{ll}
R & S \\
T & U
\end{array}\right]
$$

alakban, ahol az $\boldsymbol{R}$ mátrix a bal felső $6 \times 6$-os blokk, és az egyes blokkok $c=4$ esetén: 


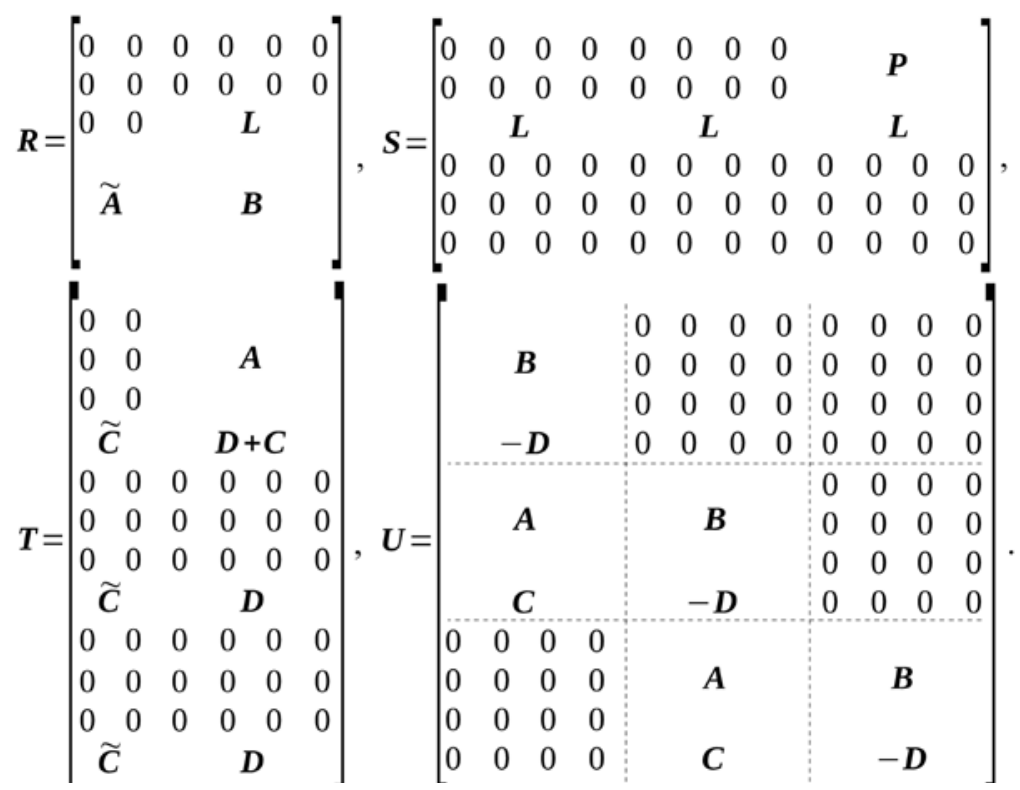

Amennyiben a kvadratikus $\boldsymbol{U}$ mátrix nem szinguláris, úgy a frekvenciamátrix determinánsa előállítható a

$$
|\boldsymbol{F}|=|\boldsymbol{U}| \cdot\left|\boldsymbol{R}-\boldsymbol{S} \boldsymbol{U}^{-1} \boldsymbol{T}\right|
$$

alakban (Rózsa 1991). Az $\boldsymbol{U}$ mátrixot a (9) egyenletben szaggatott vonalakkal 4×4-es blokkokra bontottuk: a fóátlóblokkok a $\boldsymbol{B}$ és $-\boldsymbol{D}$, a fóátló alatti blokkok pedig az $\boldsymbol{A}$ és $\boldsymbol{C}$ mátrixokból állíthatók elö. E felbontás alapján kijelenthető, hogy ez a mátrix egy Toeplitz típusú, kontinuáns alsó háromszög hipermátrix. Az alsó háromszög hipermátrix determinánsa a fóátló-blokkok determinánsainak szorzata. Egy-egy $4 \times 4$ es fóátló-blokk determinánsa -4 , ezért $|\boldsymbol{U}|=(-4)^{c-1}$, ami nem zérus, tehát az $\boldsymbol{U}$ mátrix inverze is létezik. A Toeplitz típusú, kontinuáns hipermátrix inverze egy Toeplitz típusú alsó háromszög hipermátrix, melynek struktúrája az alábbi:

$$
\boldsymbol{U}^{-1}=\left[\begin{array}{ccccc}
\boldsymbol{X} & \mathbf{0} & \mathbf{0} & \mathbf{0} & \ldots \\
\boldsymbol{Z} \boldsymbol{X} & \boldsymbol{X} & \mathbf{0} & \mathbf{0} & \ldots \\
\boldsymbol{Z}^{2} \boldsymbol{X} & \boldsymbol{Z} \boldsymbol{X} & \boldsymbol{X} & \mathbf{0} & \ldots \\
\boldsymbol{Z}^{3} \boldsymbol{X} & \boldsymbol{Z}^{2} \boldsymbol{X} & \boldsymbol{Z} \boldsymbol{X} & \boldsymbol{X} & \ldots \\
\ldots & \ldots & \ldots & \ldots & \ddots
\end{array}\right], \text { ahol } \boldsymbol{X}=\left[\begin{array}{l}
\boldsymbol{B} \\
\boldsymbol{D}
\end{array}\right]^{-1} \text { és } \boldsymbol{Z}=-\boldsymbol{X}\left[\begin{array}{l}
\boldsymbol{A} \\
\boldsymbol{C}
\end{array}\right] .
$$


A két segédmátrix kifejtve:

$$
\boldsymbol{X}=\frac{1}{2}\left[\begin{array}{cccc}
1 & 0 & 1 & 0 \\
0 & -1 & 0 & -1 \\
-1 & 0 & -1 & 0 \\
0 & -1 & 0 & 1
\end{array}\right] \text { és } \boldsymbol{Z}=\left[\begin{array}{cccc}
\cos (2 \lambda \Delta) & \sin (2 \lambda \Delta) & 0 & 0 \\
-\sin (2 \lambda \Delta) & \cos (2 \lambda \Delta) & 0 & 0 \\
0 & 0 & \cosh (2 \lambda \Delta) & \sinh (2 \lambda \Delta) \\
0 & 0 & \sinh (2 \lambda \Delta) & \cosh (2 \lambda \Delta)
\end{array}\right]
$$

Egy adott szerkezet sajátrezgéseihez tartozó frekvenciaparaméterek meghatározásához tehát azokat a $\lambda$ értékeket kell kiszámolnunk, ahol a (10) egyenlet szerinti egyszerüsített mátrix-determináns előjelt vált. Folytonos szerkezetről lévén szó, végtelen ilyen megoldás létezik.

Egy-egy $\lambda_{k}$ frekvenciaparaméter ismeretében a következő lépés a rezgésalak számítása. Ez a szinguláris $\boldsymbol{F}$ mátrix nullterének számítását jelenti, azaz tipikusan $\lambda_{k}$ behelyettesítése után egy $\boldsymbol{c}_{k}$ vektor kiszámítását, majd az általa meghatározott $u_{k}(x)$ sajátrezgésalak normálását. Utóbbira válasszuk az $L^{(2)}$ normát, azaz skálázzuk az $u_{k}(x)$ függvényt úgy, hogy teljesüljön az

$$
\int_{-0,5}^{0,5} u_{k}^{2}(x) d x=1
$$

feltétel.

\subsection{KÖZÉPPONTBAN FELFÜGGESZTETT GERENDA}

Most is csak a fél gerendaszakaszt vizsgáljuk a tartó közepétől a végéig, és az egyes szakaszokon a $\xi$ paramétert mindig 0 -tól indítjuk az $x$ koordináta eltolásával. A szakaszok végén most is $2 \Delta$ lesz a $\xi$ értéke. Ez alól egy kivétel van, az utolsó szakasz, melynek hossza $\delta=0,5-2 c \Delta$. Az alakfüggvényt az alábbiak szerint adjuk meg:

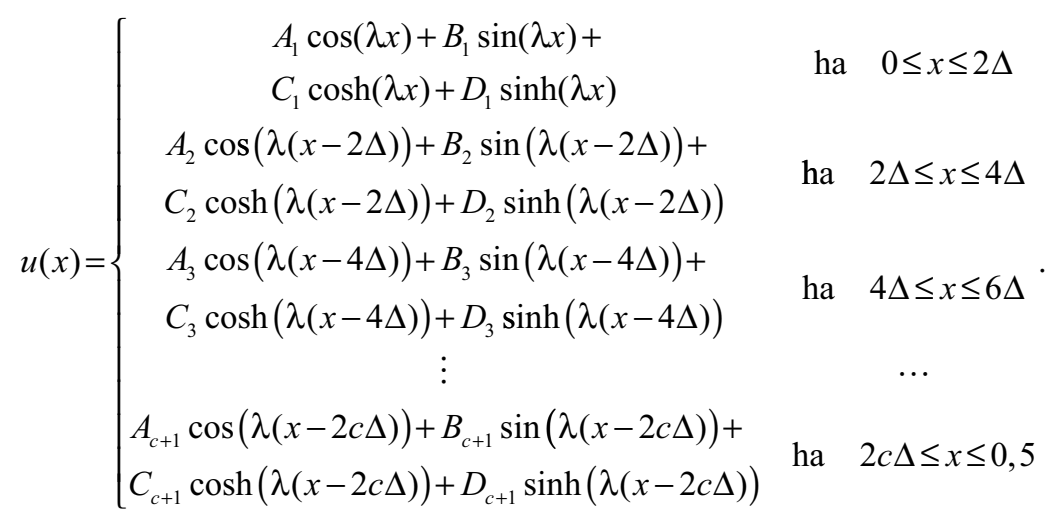


A perem- és csatlakozási feltételek a következők.

Az első két feltétel most is a tartó végén levő csuklós megtámasztás. Itt az eltolódás és a hajlítónyomaték zérus. Ez azonos a (3) egyenletben megfogalmazott két feltétellel, így azt nem ismételjük meg.

A harmadik feltétel a kötél megnyúlására vonatkozik, eszerint a felfüggesztési pontok eltolódásainak összege zérus. A szimmetrikus alakok miatt a vizsgált félen levő felfüggesztési pontok eltolódásainak összegének kétszereséhez kell a középső pont eltolódását hozzáadni. Célszerủen minden felfüggesztési pont eltolódását az azt követő szakasz függvényével írhatjuk fel, így ez a feltétel (a $\sin 0=\sinh 0=0$ és $\cos 0=\cosh 0=1$ következtében) az alábbi alakkal egyenértékü:

$$
\frac{\left(A_{1}+C_{1}\right)}{2}+\sum_{r=1}^{c}\left(A_{r+1}+C_{r+1}\right)=0 .
$$

A következő csoport a folytonossági feltételek. A középső felfüggesztési pontban azt kell biztosítanunk, hogy a balról, illetve jobbról kapott eltolódások, elfordulások és hajlítónyomatékok azonosak legyenek, de a szerkezet szimmetriája miatt ez csak az elfordulásra, tehát az első deriváltra nem teljesül automatikusan:

$$
u_{1}^{\prime}(0)=\lambda\left\{+B_{1}+D_{1}\right\}=0 .
$$

A többi felfüggesztési pontban (minden $r$-re) biztosítani kell a folytonosságot, amit a függvényérték, az első derivált és a második derivált folytonossági feltételét jelenti. Ezt fejeztük ki korábban a (6) egyenlettel, így azt nem ismételjük meg itt.

A nyíróerő kötélerő miatti ugrásának ugyanakkorának kell lenni, mint a középső felfüggesztési pontban. Ezt most is a harmadik derivált ugrásaként adjuk meg, a középső pontban pedig a harmadik derivált értékének kétszereseként:

$$
\begin{aligned}
& \left(-2 u_{1}^{\prime \prime \prime}(0)\right)-\left(u_{r}^{\prime \prime \prime}(2 \lambda \Delta)-u_{r+1}^{\prime \prime \prime}(0)\right)=\lambda^{3}\left\{\left(+2 B_{1}-2 D_{1}\right)-\right. \\
& \left.-\left(A_{r} \sin (2 \lambda \Delta)-B_{r} \cos (2 \lambda \Delta)+C_{r} \sinh (2 \lambda \Delta)+D_{r} \cosh (2 \lambda \Delta)+B_{r+1}-D_{r+1}\right)\right\}=0 .
\end{aligned}
$$

Az ismeretleneket a $\boldsymbol{c}=\left[A_{1}, B_{1}, C_{1}, D_{1}, A_{2}, B_{2}, C_{2}, D_{2}, \ldots D_{c+1}\right]^{T}$ vektorba gyüjtve a fenti feltételeket röviden $\boldsymbol{F} \boldsymbol{c}=0$ alakban is írhatjuk, ahol $\boldsymbol{F}$ a frekvenciamátrix. A frekvenciamátrix egy-egy sora az előbb ismertetett feltételek egyikét tartalmazza. Írjuk a feltételi egyenleteket az ismertetés sorrendjében, az egyes felfüggesztési pontokhoz tartozó (6) és (13) egyenleteket összevonva, és ahol lehetséges, a $\lambda$ hatványával leosztva egyszerüsítsük azokat. Így az egyenletrendszer mátrixos alakja $c=3$ esetben az alábbi lesz: 


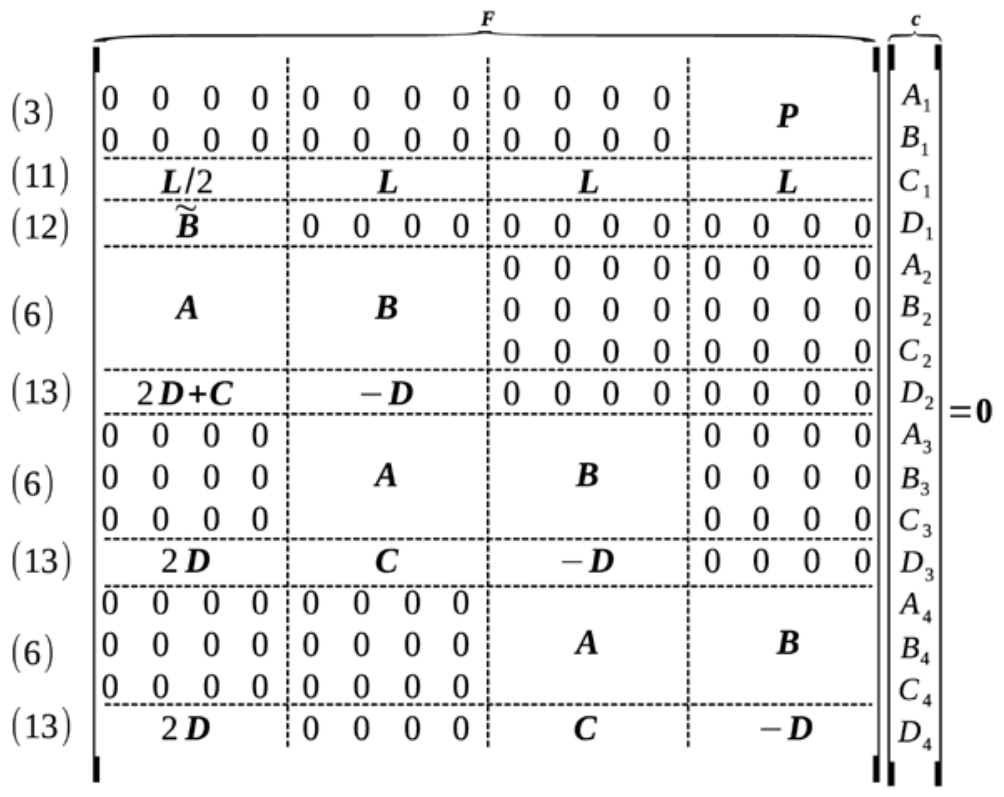

A mátrixot vízszintesen a (3), (11-12), (6), (13) feltételi egyenletek szerint osztottuk fel szaggatott vonalakkal, függőlegesen pedig az egyes gerendaszakaszokhoz tartozó paraméterek együtthatóinak megfelelően rajzoltunk be szaggatott vonalakat. Az egyes mátrixsorok csoportjai előtt jeleztük az adott sorokat meghatározó egyenleteket. A mátrix nemzérus elemeit a korábban már bevezetett segédmátrixok segítségével adtuk meg a (14) egyenletben, az egyetlen új tag:

$$
\tilde{\boldsymbol{B}}=\left[\begin{array}{llll}
0 & 1 & 0 & 1
\end{array}\right] .
$$

A mátrix struktúrájára az előző esethez hasonló megállapítást tehetünk. Újabb felfüggesztési pont esetén a sorok és oszlopok száma is néggyel növekszik, a $\boldsymbol{P}$ blokk jobbra tolódik négy hellyel, helyére egy $2 \times 4$-méretü zérusmátrix kerül. A harmadik sorban a $\boldsymbol{P}$ mátrix alatt egy $\boldsymbol{L}$ blokk jelenik meg. A mátrix utolsó sorának elejére egy [2D] blokk kerül, míg a jobb alsó sarokban levő $4 \times 8$-as blokkhoz az

$$
\left[\begin{array}{cc}
A & B \\
C & -D
\end{array}\right]
$$

blokkot kell hozzáadni. Ezzel a recepttel a mátrix tetszőleges számú felfüggesztési pontra felírható.

A mátrix struktúrája ebből a felírásból már jól kiolvasható. 
Visszafelé haladva a felfüggesztési pontok számának csökkentésével most a $c=0$ eset lenne a határhelyzet. (Ez az eset a középen és két végpontjában megtámasztott gerenda szimmetrikus rezgésalakjait adná vissza a $\Delta$ paramétertől függetlenül.) Ehhez az esethez már csak a 4×4-es méretü

$$
\left[\begin{array}{c}
\boldsymbol{P} \\
\boldsymbol{L} / 2 \\
\tilde{\boldsymbol{B}}
\end{array}\right]
$$

mátrix tartozik.

A $\lambda$ frekvenciaparaméterek most is azok az értékek, ahol a (14) egyenlet alakjában megadott homogén egyenletnek nemtriviális megoldása van, azaz az $\boldsymbol{F}$ determinánsa 0 . A számítási igény itt is jelentősen csökkenthető a mátrix speciális szerkezetének kihasználásával.

Particionáljuk a frekvenciamátrixot

$$
F=\left[\begin{array}{ll}
R & S \\
T & U
\end{array}\right]
$$

alakban, ahol az $\boldsymbol{R}$ mátrix a bal felső $4 \times 4$-es blokk, és az egyes blokkok $c=3$ esetén:

$$
\begin{aligned}
& \boldsymbol{R}=\left[\begin{array}{cccc}
0 & 0 & 0 & 0 \\
0 & 0 & 0 & 0 \\
& \boldsymbol{L} / 2 \\
& \widetilde{\boldsymbol{B}}
\end{array}\right], \quad \boldsymbol{S}=\left[\begin{array}{cccccccccccc}
0 & 0 & 0 & 0 & 0 & 0 & 0 & 0 & & \boldsymbol{P} & \\
0 & 0 & 0 & 0 & 0 & 0 & 0 & 0 & & \multicolumn{1}{c}{} & \\
& \boldsymbol{L} & & & & \boldsymbol{L} & & & \boldsymbol{L} & \\
0 & 0 & 0 & 0 & 0 & 0 & 0 & 0 & 0 & 0 & 0 & 0
\end{array}\right],
\end{aligned}
$$

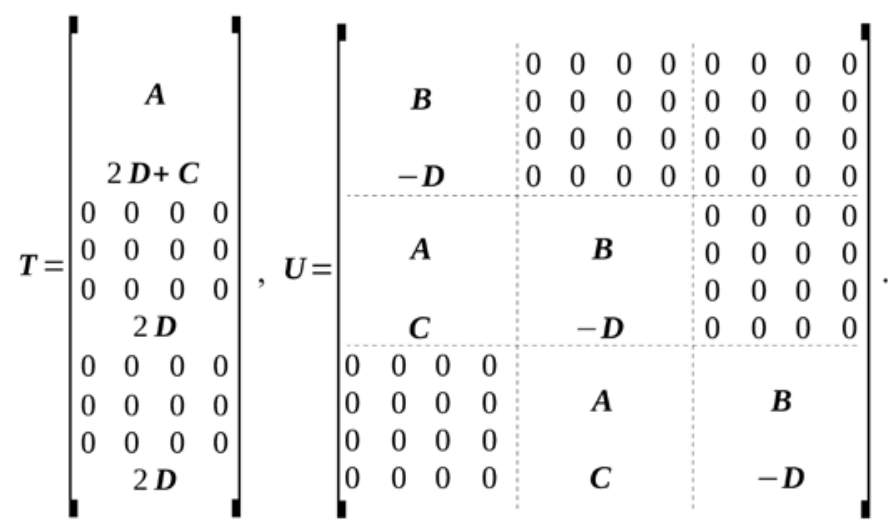

Itt is elmondható, hogy amennyiben a kvadratikus $\boldsymbol{U}$ mátrix nem szinguláris, úgy a frekvenciamátrix determinánsa elóállítható a (10) egyenlet segítségével. Mivel az $\boldsymbol{U}$ mátrix alakja megegyezik (9) és (15) egyenletben, ezért külön bizonyítás nélkül kijelenthetjük, hogy az inverz létezik és a korábban bemutatott módon számítható.

Egy adott szerkezet sajátrezgéseihez tartozó frekvenciaparaméterek meghatározásához tehát azokat a $\lambda$ értékeket kell kiszámolnunk, ahol a (10) egyenlet szerinti 
egyszerüsített mátrix-determináns előjelet vált. Folytonos szerkezetről lévén szó, végtelen ilyen megoldás létezik.

Egy-egy $\lambda_{k}$ frekvenciaparaméter ismeretében a következő lépés a rezgésalak számítása. Ez a szinguláris $\boldsymbol{F}$ mátrix nullterének számítását jelenti, azaz tipikusan $\lambda_{k}$ behelyettesítése után egy $\boldsymbol{c}_{k}$ vektor kiszámítását, majd az általa meghatározott $u_{k}(x)$ sajátrezgésalak normálását. Utóbbira itt is az $L^{(2)}$ normát használjuk.

\section{PÉLDÁK, EREDMÉNYEK}

Az előző fejezetben bemutatott módszer használatára három példát mutatunk.

Az első példánkban a gerendát négy pontban függesztjük fel, tehát ez egy páros felfüggesztési pontú szerkezet, ahol $c=2$. Legyen a kötélszakasz vízszintes vetülete $\Delta=1 / 6$. Ez azonos szerkezet egy korábban vizsgálttal (Kocsis 2015), így az eredmények összevethetők lesznek. A behelyettesítés után a (10) egyenletnek megfelelöen redukált mátrix alakja:

$$
\boldsymbol{R}-\boldsymbol{S} \boldsymbol{U}^{-1} \boldsymbol{T}=\left[\begin{array}{cccccc}
0 & 0 & \cos \left(\frac{\lambda}{3}\right) & \sin \left(\frac{\lambda}{3}\right) & \cosh \left(\frac{\lambda}{3}\right) & \sinh \left(\frac{\lambda}{3}\right) \\
0 & 0 & -\cos \left(\frac{\lambda}{3}\right) & -\sin \left(\frac{\lambda}{3}\right) & \cosh \left(\frac{\lambda}{3}\right) & \sinh \left(\frac{\lambda}{3}\right) \\
0 & 0 & \cos \left(\frac{\lambda}{3}\right)+1 & \sin \left(\frac{\lambda}{3}\right) & \cosh \left(\frac{\lambda}{3}\right)+1 & \sinh \left(\frac{\lambda}{3}\right) \\
\cos \left(\frac{\lambda}{6}\right) & \cosh \left(\frac{\lambda}{6}\right) & -1 & 0 & -1 & 0 \\
-\sin \left(\frac{\lambda}{6}\right) & \sinh \left(\frac{\lambda}{6}\right) & 0 & -1 & 0 & -1 \\
-\cos \left(\frac{\lambda}{6}\right) & \cosh \left(\frac{\lambda}{6}\right) & 1 & 0 & -1 & 0
\end{array} \mid\right.
$$

A (10) egyenlet szerinti szorzatban az első tag nem nulla, tehát a fenti mátrix determinánsának kell nullának lennie. Például ha

$$
\lambda=\lambda_{k}=4,1038 \pi,
$$

akkor a determináns csak a kerekítési hibák nagyságrendjében tér el nullától. Az eredeti frekvenciamátrixba visszahelyettesítve a rezgésalakot meghatározó $\boldsymbol{c}_{k}$ vektor egy lehetséges értéke:

$$
\begin{gathered}
c=\left[\begin{array}{cccccc}
1 & 0,1257 & -0,5463 & 0,2406 & 0,5463 & 0,5465 \ldots \\
\ldots & 0 & 0,4813 & 0 & -1,0931
\end{array}\right]^{T} .
\end{gathered}
$$


A fenti paraméterekkel felírt $u_{k}(x)$ függvény $L^{(2)}$ normáját kiszámolva tudjuk skálázni a rezgésalakot:

$$
\begin{gathered}
c=\left[\begin{array}{cccccc}
1,853 & 0,2329 & -1,012 & 0,4459 & 1,012 & -1,013 \ldots \\
\ldots 0 & 0,8919 & 0 & -2,026
\end{array}\right]^{T} .
\end{gathered}
$$

Az ehhez tartozó rezgésalakot a 2. ábrán mutatjuk be, ami jó egyezést mutat (Kocsis 2015) eredményével.

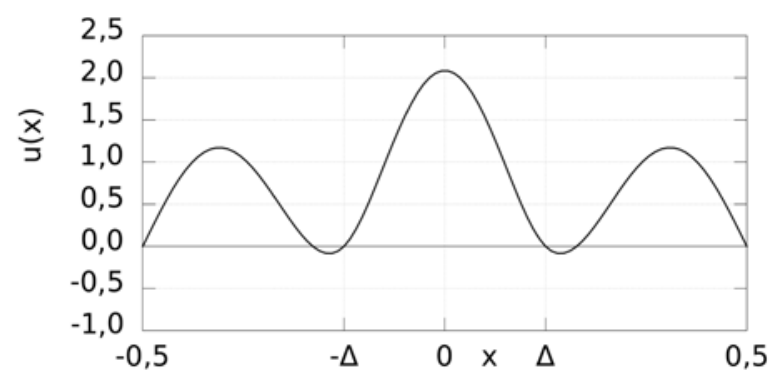

2. ábra. Egységnyi hosszúságú gerenda normált rezgésalakja

Amennyiben ismerjük a gerenda $E I$ hajlítómerevségét, $\mu$ fajlagos tömegét és a nem egységnyi $L$ hosszát, akkor a sajátkörfrekvenciát az

$$
\omega_{0, k}=\frac{\lambda_{k}^{2}}{L^{2}} \sqrt{\frac{E I}{\mu}}
$$

képlettel számíthatjuk. A normált rezgésalak felírásakor a nemzérus hosszt két helyen kell figyelembe vennünk: szakaszonként a (2) szerinti függvénybe való behelyettesítésnél $x$ helyére $\left(x-x_{0}\right) / L$ írandó, a teljes függvényt pedig $L$ négyzetgyökével kell osztani. Így jelen esetben:

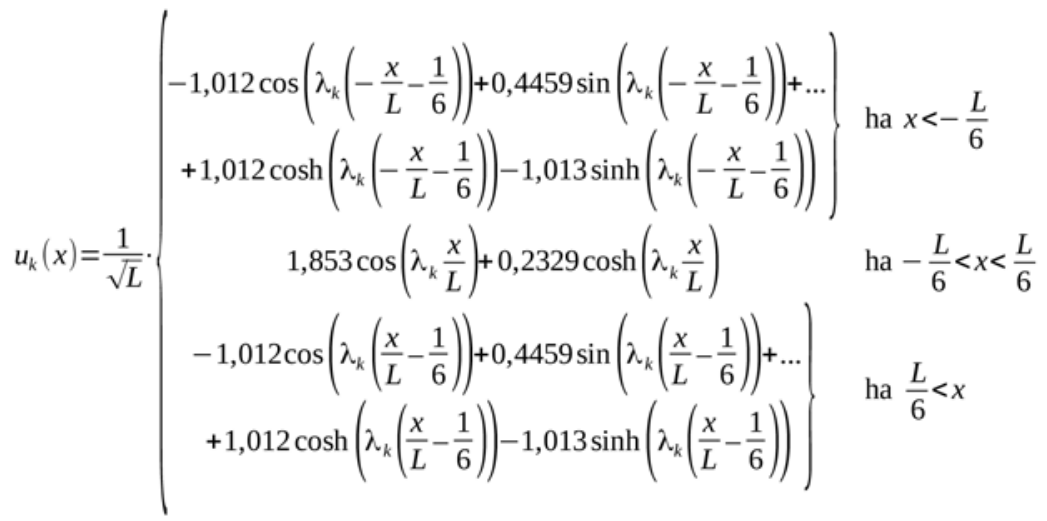

(Látható, hogy $A_{3}, B_{3}, C_{3}, D_{3}$ paraméterekre nem is volt szükség, hiszen annak a szakasznak 0 a hossza.) 
A második példában a gerendát három pontban függesztjük fel, tehát ez egy páratlan felfüggesztési pontú szerkezet, ahol $c=1$. Legyen a kötélszakasz vízszintes vetülete most is $\Delta=1 / 6$. A behelyettesítés után a (10) egyenletnek megfelelően redukált mátrix alakja:

$$
\begin{aligned}
& \boldsymbol{R}-\boldsymbol{S} \boldsymbol{U}^{-1} \boldsymbol{T}= \\
& \int \cos \left(\frac{\lambda}{3}\right) \cos \left(\frac{\lambda}{6}\right)-\sin \left(\frac{\lambda}{3}\right) \sin \left(\frac{\lambda}{6}\right) \sin \left(\frac{\lambda}{6}\right)\left(\cos \left(\frac{\lambda}{3}\right)+1\right)-\sinh \left(\frac{\lambda}{6}\right)+\cos \left(\frac{\lambda}{6}\right) \sin \left(\frac{\lambda}{3}\right) \\
& =\sin \left(\frac{\lambda}{3}\right) \sin \left(\frac{\lambda}{6}\right)-\cos \left(\frac{\lambda}{3}\right) \cos \left(\frac{\lambda}{6}\right)-\sinh \left(\frac{\lambda}{6}\right)-\sin \left(\frac{\lambda}{6}\right)\left(\cos \left(\frac{\lambda}{3}\right)+1\right)-\cos \left(\frac{\lambda}{6}\right) \sin \left(\frac{\lambda}{3}\right) \ldots \\
& \cos \left(\frac{\lambda}{3}\right)+1 / 2 \quad \sin \left(\frac{\lambda}{3}\right) \\
& 1 \\
& \left.\cosh \left(\frac{\lambda}{3}\right) \cosh \left(\frac{\lambda}{6}\right)+\sinh \left(\frac{\lambda}{3}\right) \sinh \left(\frac{\lambda}{6}\right) \sinh \left(\frac{\lambda}{6}\right)\left(\cosh \left(\frac{\lambda}{3}\right)+1\right)-\sin \left(\frac{\lambda}{6}\right)+\cosh \left(\frac{\lambda}{6}\right) \sinh \left(\frac{\lambda}{3}\right)\right) \\
& \ldots \cosh \left(\frac{\lambda}{3}\right) \cosh \left(\frac{\lambda}{6}\right)+\sinh \left(\frac{\lambda}{3}\right) \sinh \left(\frac{\lambda}{6}\right) \sin \left(\frac{\lambda}{6}\right)+\sinh \left(\frac{\lambda}{6}\right)\left(\cosh \left(\frac{\lambda}{3}\right)+1\right)+\cosh \left(\frac{\lambda}{6}\right) \sinh \left(\frac{\lambda}{3}\right) \\
& \cosh \left(\frac{\lambda}{3}\right)+1 / 2 \\
& 0 \\
& \sinh \left(\frac{\lambda}{3}\right)
\end{aligned}
$$

A (10) egyenlet szerinti szorzatban az első tag nem nulla, tehát a fenti mátrix determinánsának kell nullának lennie. Például ha

$$
\lambda=\lambda_{k}=2,816 \pi,
$$

akkor a determináns csak a kerekítési hibák nagyságrendjében tér el nullától. Az eredeti frekvenciamátrixba visszahelyettesítve a rezgésalakot meghatározó $c$ vektor egy lehetséges értéke:

$$
\begin{gathered}
c=\left[\begin{array}{cccccc}
1 & 0,02765 & -0,3038 & -0,2764 & -0,9285 & 0,0899 \ldots \\
\ldots & 0,2764 & 0,3070
\end{array}\right]^{T} .
\end{gathered}
$$

A fenti paraméterekkel felírt $u_{k}(x)$ függvény $L^{(2)}$ normáját kiszámolva tudjuk skálázni a rezgésalakot:

$$
\begin{aligned}
& c=\left[\begin{array}{llllll}
1,398 & 0,3865 & 0,4247 & -03863 & -1,298 & 0,1256 \ldots
\end{array}\right. \\
& \text {.. } 0,38630,4291]^{T} \text {. }
\end{aligned}
$$

Az ehhez tartozó rezgésalakot a 3. ábrán mutatjuk be. 


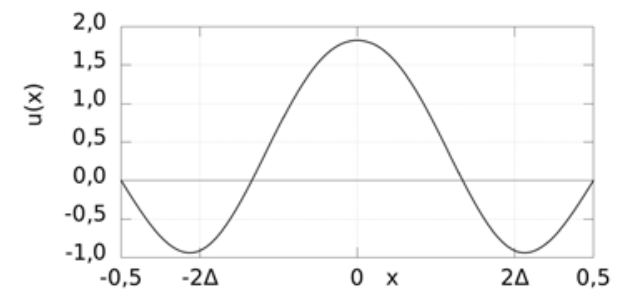

3. ábra. Egységnyi hosszúságú gerenda normált rezgésalakja

Amennyiben ismerjük a gerenda $E I$ hajlítómerevségét, $\mu$ fajlagos tömegét és a nem egységnyi $L$ hosszát, akkor a sajátkörfrekvenciát a

$$
\omega_{0, k}=\frac{\lambda_{k}^{2}}{L^{2}} \sqrt{\frac{E I}{\mu}}
$$

képlettel számíthatjuk. A normált rezgésalaknál itt is az előző megfontolásokat kell követni, azaz:

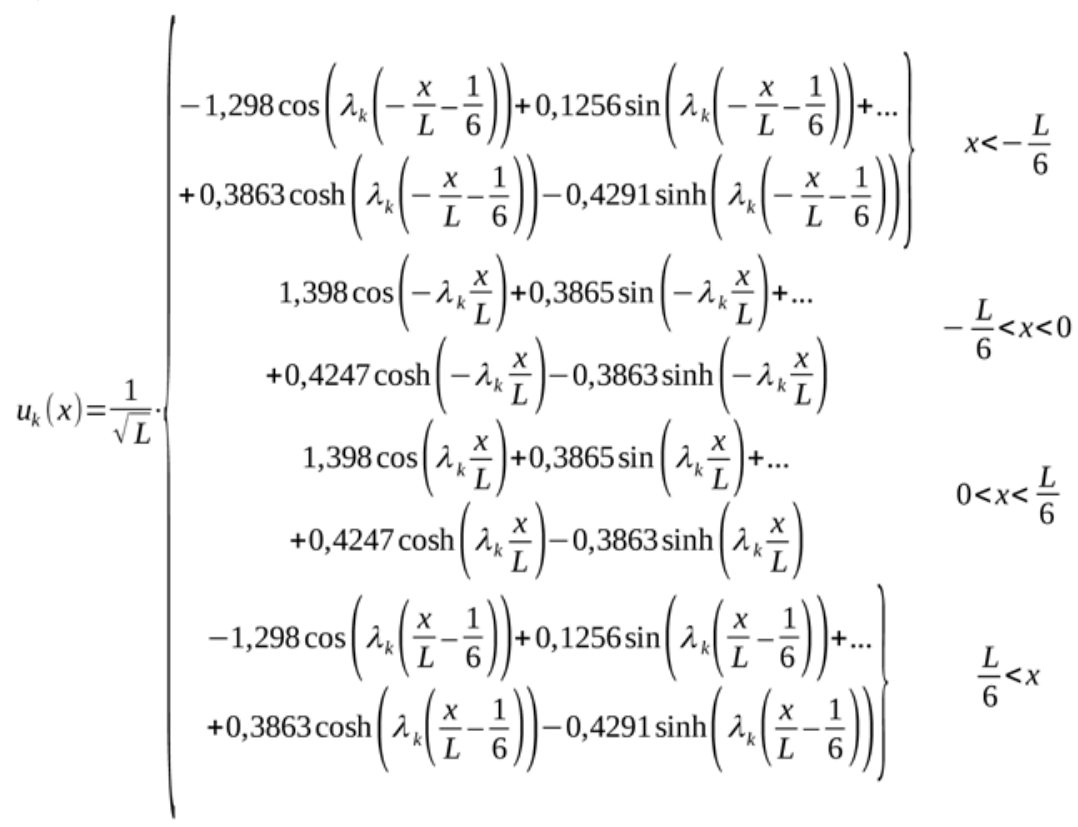

függvénnyel írhatjuk le.

Harmadik példánkban páros felfüggesztési pont esetén mutatjuk meg a frekvenciaparamétereket abban az esetben, ha a $\Delta$ paraméter értéke nullához tart. Határátmenetben a frekvenciamátrixot alkotó mátrixok egyszerüsödnek. Egyedül a $\boldsymbol{P}$ mátrixban marad meg a frekvenciaparaméter: 


$$
\boldsymbol{P}=\left[\begin{array}{cccc}
\cos (\lambda / 2) & \sin (\lambda / 2) & \cosh (\lambda / 2) & \sinh (\lambda / 2) \\
-\cos (\lambda / 2) & -\sin (\lambda / 2) & \cosh (\lambda / 2) & \sinh (\lambda / 2)
\end{array}\right],
$$

a többi mátrix viszont attól független lesz:

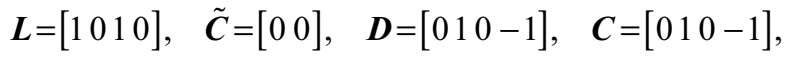

$$
\begin{aligned}
& \tilde{\boldsymbol{A}}=\left[\begin{array}{cc}
1 & 1 \\
0 & 0 \\
-1 & 1
\end{array}\right], \quad \boldsymbol{B}=\left[\begin{array}{cccc}
-1 & 0 & -1 & 0 \\
0 & -1 & 0 & -1 \\
1 & 0 & -1 & 0
\end{array}\right], \quad \boldsymbol{A}=\left[\begin{array}{cccc}
1 & 0 & 1 & 0 \\
0 & 1 & 0 & 1 \\
-1 & 0 & 1 & 0
\end{array}\right] .
\end{aligned}
$$

A konstanselemü mátrixok miatt a determináns számítása lényegesen egyszerüsödik. A részletek kifejtése nélkül a determináns zérus voltát az alábbi egyenlet fejezi ki:

$$
2\left(\cos \left(\frac{\lambda}{2}\right) \sinh \left(\frac{\lambda}{2}\right)-\sin \left(\frac{\lambda}{2}\right) \cosh \left(\frac{\lambda}{2}\right)\right)=0 .
$$

Ez az egyenlet egyenértékü az $x=0$ helyen befogott, $x=0,5$ helyen csuklósan megtámasztott gerenda frekvenciaparamétereinek számítására szolgáló egyenlettel. Ennek oka, hogy a határátmenetben a gerenda közepébe kerülö felfüggesztési pontok nem engedik az $x=0$ pont eltolódását és elfordulását sem.

\section{5. ÖSSZEFOGLALÁS}

Cikkünkben bemutattuk a csigasorral felfüggesztett tartó aktív felfüggesztéshez tartozó sajátrezgéseinek körfrekvenciáinak számítását. Módszert adtunk a több elmozdulás kombinációjára feltételt adó kényszer hatásának a frekvenciaparaméter számítása során való figyelembevételére a felfüggesztések helyzetének függvényében. A frekvenciamátrix struktúráját kihasználva csökkenthető annak a mátrixnak a mérete, mely determinánsának zérushelyei a szerkezet frekvenciaparamétereinek számítására szolgálnak. A frekvenciaparaméterek ismeretében a sajátkörfrekvencia és a rezgésalakok számíthatók.

\section{IRODALOM}

Hincz, Krisztián: Arch-supported tensile structures with very long clear spans. Journal of the International Association for Shell and Spatial Structures 48 (2007) 2. 89-98.

Hincz, Krisztián: Nonlinear analysis of cable net structures suspended from arches with block and tackle suspension system, taking into account the friction of the pulleys. International Journal of Space Structures 24 (2009) 3. 143-152.

Kocsis, Attila - Németh, Róbert K. - Turmunkh, Baigalimaa: Dynamic analysis of a beam on block-andtackle suspension system: A continuum approach. Engineering Structures 101 (2015) 412-426.

Kolozsváry-Kiss, Árpád: Roof arches without bending moments. Patent, WO/2006/136867; 2006. 
Ludvig Győző: Gépek dinamikája. Müszaki Könyvkiadó, Budapest 1983.

Németh Róbert K. - Kocsis Attila: Csigasorral függesztett gerenda szabadrezgése modálanalízissel. In: XII. Magyar Mechanikai Konferencia. Szerk.: Baksa Attila - Bertóti Edgár - Szirbik Sándor. Miskolci Egyetem Gépészmérnöki és Informatikai Kar Műszaki Mechanikai Intézet, Miskolc 2015. 1-9.

Rózsa Pál: Lineáris algebra és alkalmazásai. Tankönyvkiadó, Budapest 1991.

Timoshenko, Stephen - Young, Donovan H. - Weaver, W.: Vibration problems in engineering. John Wiley \& Sons, New York 1974.

\title{
FREE VIBRATION OF A FAMILY OF SUSPENDED BEAMS I.
}

\section{CALCULATION OF NATURAL FREQUENCIES AND MODAL SHAPES}

\begin{abstract}
Summary
In this paper the effects of a new kind of structure, the block-and-tackle suspension system, are investigated on the free vibration of a beam family subjected to bending. The beam family consists of symmetric pinned-pinned beams that are supported by an infinitely stiff cable with neglectable mass connected symmetrically by the block-and-tackle system. The inertia of the pulleys and their friction is neglected. Two possible states of the cable results in a typically nonlinear structural behavior, but each state can be analyzed as a linear problem. In view of the natural frequencies and vibration modes corresponding to the tightened state of the cable, the use of modal analysis in the examination of the vibrations of the structure is possible. The vibration modes and natural frequencies are determined as a function of the frequency parameter and a parameter characterizing the position of the suspension points. This is obtained through the frequency matrix expressing the continuity and boundary conditions. Searching for the fix points of the determinant of the frequency matrix we present how the calculation of the determinant leads to the calculation of the determinant of a smaller matrix. The determinant of this smaller matrix vanishes at the same values of the frequency parameter as the determinant of the frequency matrix.
\end{abstract}

Keywords: block-and-tackle suspension, multi-freedom-constraint, free vibration 